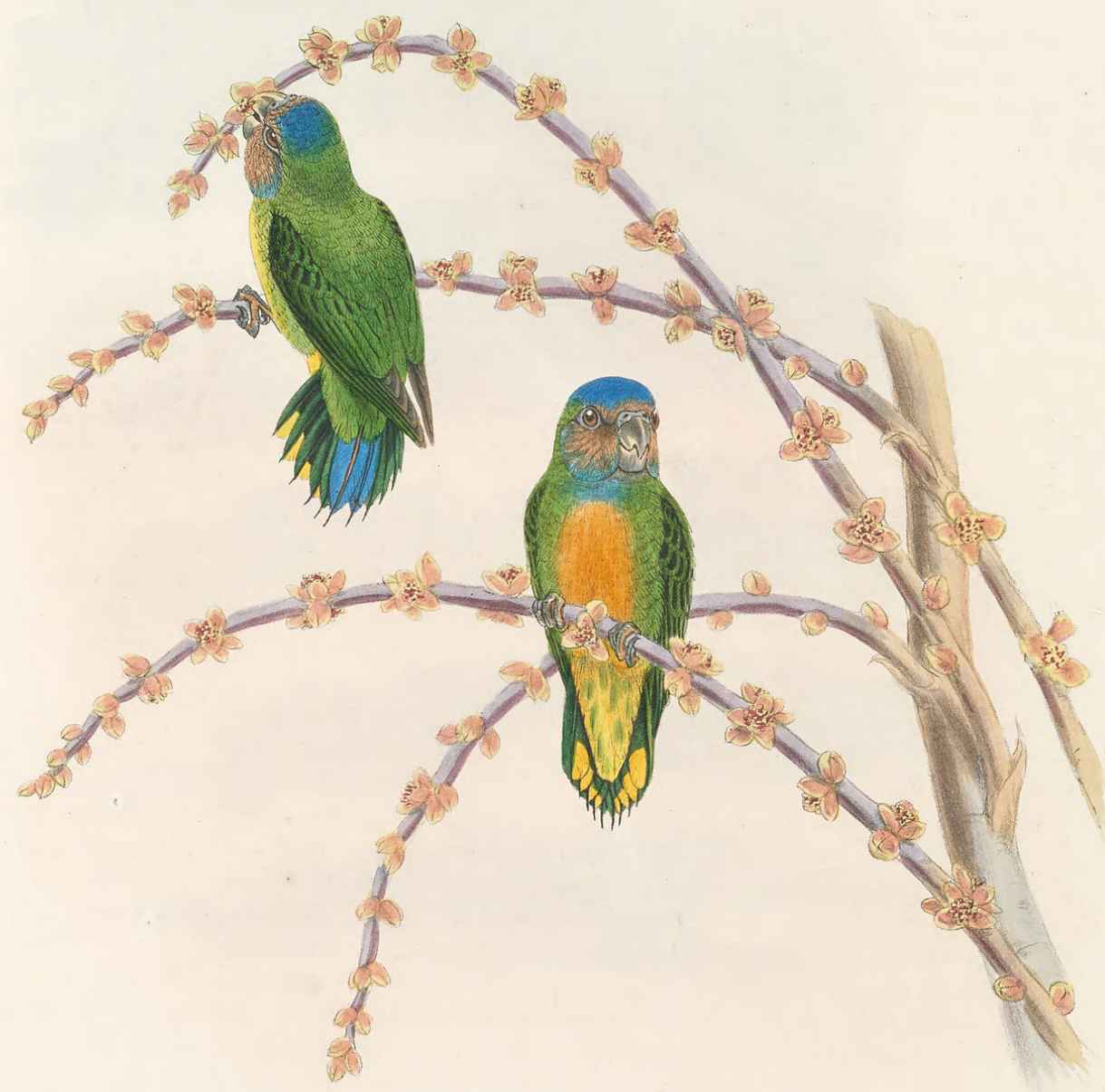




\title{
NASITERNA MAFORENSIS.
}

\section{Mafor Pygmy Parrot.}

\author{
Nasiterna pygmaa geelvinkiana (pt.), Schl. N. T. D. iv. p. 7 (1871),-Rosenb. Reist. naar Geelvinkb. p. 137 \\ (pt., 1875). \\ - geelvinkiana (pt.), Schleg. Mus. P.-B. Psittaci, Revue, p. 71 (1874).-Meyer, Sitz. Isis zu Dresden, \\ 1875 , p. 76 (pt.).-Rowley, P. Z. S. 1875 , p. 470.-Id. Orn. Misc. p. 153, pl. xviii. (1876).-Beccari, \\ Ann. Mus. Civic. Genov. vii. p. 714 (1875, pt.). \\ pygmaa, Rosenb. Reist. naar Geelvinkb. p. 36 (1875, nec Q. \& G.). \\ maforensis, Salvad. Ann. Mus. Civic. Genov. vii. p. 908 (1875).-Sclater, Ibis, 1876, p. 358.-Salvad. \\ Ann. Mus. Civic. Genov. x. p. 26 (1877).
}

As Dr. Meyer during his visit to the Island of Mafor does not appear to have procured any Nasiternce, I have been indebted to Count Salvadori and Mr. Dawson Rowley for the four examples which have been examined by me; and to the former gentleman I am under special obligations for an elaborate note on the species, as well as its complete synonymy.

The present species is very nearly allied to $N$. misoriensis; but under existing circumstances they must, in my opinion, be considered distinct species. In both of them the bills are disproportionately large, giving their faces an outré and unpleasant aspect; and the bill and feathers of the face are frequently covered with a dirty glutinous substance, which does not improve their appearance.

Count Salvadori writes to me as follows :- "This species is peculiar to the island of Mafor. Both male and female have the crown blue; and in this respect $N$. maforensis differs from $N$. misoriensis. When I discriminated the two species I would willingly have left Schlegel's name of geelvinkiana to the bird of Mafor; but as the latter name, which belongs equally to both species, would have been a constant source of confusion, I thought it better to give a new title to the Mafor bird also.

“' This is the species figured by Mr. Dawson Rowley in his 'Ornithological Miscellany;' but the description given by Dr. Finsch in the same work, under the heading of $N$. geelvinkiana, probably applies to the female of the Misori bird.

"Von Rosenberg has the following remarks on the present species :- - The small Nasiterna is common ; and the natives, who are very clever, brought me several specimens, alive and dead, of the adult and young. This pretty little bird is especially abundant in the neighbourhood of Roemsaro. It nests in the holes of trees; and the female lays two eggs, not larger than those of our Long-tailed Titmouse (Parus caudatus). They breed in January and February, which is the breeding-season also for other Parrots."'

The following diagnosis of the species has been sent to me by Count Salvadori :-

"Adult male. Green; pileum brown, the feathers edged with bright blue; cheeks brown, with the edges of some of the feathers bluish; nape green like the back, with a yellowish-green spot in the middle, not very conspicuous; centre of the breast and of the abdomen ochraceous yellow ; under tail-coverts and a spot at the tip of the three outer tail-feathers yellow, the lateral ones black, the outer ones edged with green.

"Female. Like that of $N$. misoriensis, but the feathers of the crown edged with brighter blue. Dimensions nearly the same as those of $N$. misoriensis."

The figures in the Plate are those of a male and a female, of the natural size, drawn from birds lent to me by Mr. Dawson Rowley and Count Salvadori. 


\section{$2 \mathrm{BHL}$ Biodiversity Heritage Library}

Gould, John and Sharpe, Richard Bowdler. 1878. "Nasiterna maforensis, Mafoor Pygmy Parrot [PI. 22]." The birds of New Guinea and the adjacent Papuan islands : including many new species recently discovered in Australia 5(VI), -. https://doi.org/10.5962/p.322866.

View This Item Online: https://www.biodiversitylibrary.org/item/230441

DOI: https://doi.org/10.5962/p.322866

Permalink: https://www.biodiversitylibrary.org/partpdf/322866

\section{Holding Institution}

Smithsonian Libraries

\section{Sponsored by}

Biodiversity Heritage Library

\section{Copyright \& Reuse}

Copyright Status: Public domain. The BHL considers that this work is no longer under copyright protection.

This document was created from content at the Biodiversity Heritage Library, the world's largest open access digital library for biodiversity literature and archives. Visit BHL at https://www.biodiversitylibrary.org. 